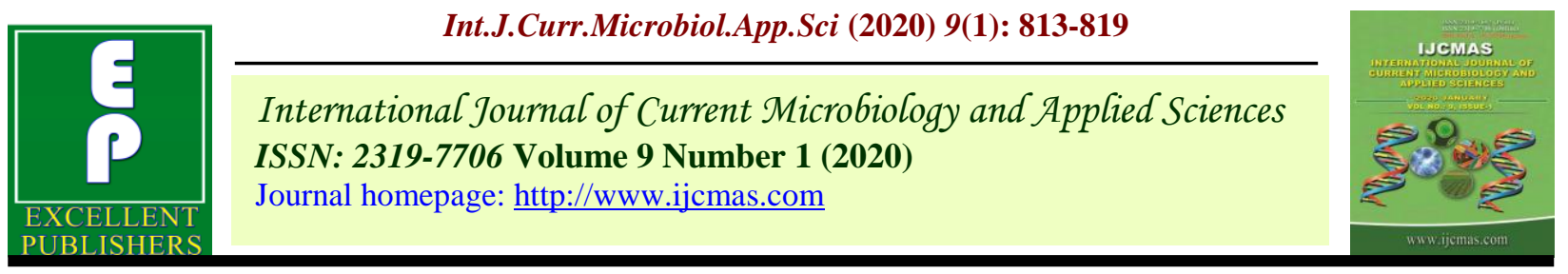

Original Research Article

https://doi.org/10.20546/ijcmas.2020.901.087

\title{
Technological Gap among Small and Marginal Farmers in Adoption of Improved Cultivation Practices of Chickpea Crop
}

\author{
A. T. Krishnamurthy ${ }^{1 *}$ and S. K. Meti ${ }^{2}$ \\ ${ }^{1}$ Department of Agricultural Extension, College of Horticulture, Mudigere, Karnataka, India \\ ${ }^{2}$ Director of Education, College of Agriculture, UAS, Raichur, Karnataka, India \\ *Corresponding author
}

\section{Keywords}

Technological gap,

Chickpea, Improved cultivation

practices, Small and marginal farmers

Article Info

Accepted:

xx December 2019

Available Online:

xx January 2020

A B S T R A C T

The study conducted in twelve villages Viz., Askihal, Yaklaspur, Amaravathi, Kuppigudda, Melakunda, Srinivas saradagi, Kollur, Maradagi, Narayanapura, Betabalakunda, Siddeshwara and Bhalki of Hyderabad-Karnataka region of Karnataka, during the year 2014- 15, to know the technological gap among the small and marginal farmers in adoption of improved cultivation practices chickpea crop. The study revealed that, majority of the small farmers $(83.33 \%)$ and marginal farmers $(43.33 \%)$ of chickpea crop belonged to medium technological gap category. Meager per cent of the technological gap was observed among the small and marginal farmers of chickpea in the practices like soil type, land preparation, sowing season, varieties, seed rate, spacing and hand weeding and huge technological gap was observed in application of FYM, intercultivation, use of herbicides, growth regulator and nipping. With regard to integrated pest management, cent per cent of both small and marginal farmers did not follow the practices like mechanical beating of plants, erection of bird perches and pheromone traps.

\section{Introduction}

Chickpea (Cicer arietinum) is the rich source of protein. The seed contains 21.10 per cent proteins, 61.50 per cent carbohydrates and 4.50 per cent fats. Besides, it contains iron, calcium \& Niacin in sufficient quantity. It has been proved very good fodder for milking animals. The tender leaves are used as vegetable. The floor is used in preparing different products. The malic acid and oxalic acid present in chickpea plant is used in medicine preparation.

Among pulses, chickpea is the most important pulse crop grown in India in 6.93 million hectare area which contributes 62 per cent of the global production (5.6 million tonnes) and about 37 per cent of total pulse production in the country. 
Chickpea is the largest produced food legume in South Asia and the third largest produced food legume globally. Chickpea is grown in more than 50 countries. Asia accounts 89.70 per cent of the area in chickpea production, followed by 4.3 per cent in Africa, 2.60 per cent in Oceania, 2.9 per cent in Americas and $0.4 \%$ in Europe. India ranked first in terms of chickpea production and consumption in the world. About 65 per cent of global area with 68 per cent of global production of chickpea is contributed by India (Amarender and Devrajmishra, 2010). India grows chickpea on about $6.86 \mathrm{~m}$ ha producing $5.35 \mathrm{~m}$ tones of grains, which represents 32 per cent and 42 per cent of the national pulse acreage and production, respectively. The major chickpea producing states viz., Madhya Pradesh, Rajasthan, Maharashtra, Uttar Pradesh, Karnataka and Andhra Pradesh together contribute 91.00 per cent of the production and 90.00 per cent of the area under chickpea.

In Karnataka, chickpea is grown in an area of $80,02,570$ hectares with production of 3, 94,904 tones, having an average productivity of $518 \mathrm{kgs}$ per ha. It is largely grown in the northern parts of the state like Kalaburgi with an area about 1,66,956 hectares, has the highest area under chickpea with production of 1,17,846 tonnes and a productivity of 743 $\mathrm{kg} / \mathrm{hectare}$, followed by Bijapur with an area of $1,19,299$ hectares, with production of 49,527 tonnes with a productivity of $437 \mathrm{~kg}$ per hectares stands second, while Raichur with an area 69,776 hacter, with production of 30,956 tonnes with a productivity of $467 \mathrm{~kg}$ per hectares stands third (Anonymous-201112).

\section{Materials and Methods}

The study was undertaken in twelve villages Viz., Askihal, Yaklaspur, Amaravathi, Kuppigudda, Melakunda, Srinivas saradagi, Kollur, Maradagi, Narayanapura, Betabalakunda, Siddeshwara and Bhalki of
Hyderabad-Karnataka region of Karnataka, during the year 2014-15, to know the technological gap among the small and marginal farmers in adoption of improved cultivation practices chickpea crop. Based on the random sampling techniques 60 small farmers and 60 marginal farmers at the rate of 5 small and 5 marginal farmers from each village were selected. Thus the total sample comprises for the study were 120 .

The data of the respondents were collected by using pretested schedule and analyzed with suitable statistical tools.

The technological gap of a particular practice was calculated by using following formula

Technological gap $=$

$$
\begin{aligned}
& \text { Maximum possible }- \text { Actual score } \\
& \text { Score obtained } \\
& \text {---------------- } \times 100 \\
& \text { Maximum possible score }
\end{aligned}
$$

The mean technological gap in chickpea cultivation practices was taken as the dependent variable. The respondents were then divided into three categories viz., Low, Medium and High based on their mean technological gap.

\begin{tabular}{|c|c|c|}
\hline Sl. No. & Category & Range \\
\hline $\mathbf{1}$ & Low & Less than (Mean $-0.425 \mathrm{SD})$ \\
\hline $\mathbf{2}$ & Medium & Between (Mean $\pm 0.425 \mathrm{SD})$ \\
\hline $\mathbf{3}$ & High & More than (Mean +0.425 \\
\hline
\end{tabular}

Results and Discussion

Overall technological gap regarding improved cultivation practices chickpea among small and marginal farmers

It is clear from the Table 1 and Figure 1 that, Majority $(83.33 \%)$ of the small farmers of chickpea crop belonged to medium 
technological gap category, followed by low $(13.33 \%)$ and high $(3.33 \%)$ technological gap categories. Further, 43.33 per cent of the marginal farmers of chickpea crop belonged to medium technological gap category, followed by high $(38.33 \%)$ and medium $(18.33 \%)$ technological gap categories in chickpea crop.

As per the Mann Whitney-U test analysis, there was a significant difference existed among the small and marginal farmer categories in technological gap of improved cultivation practices of chickpea.

Technological gap with respect to individual improved cultivation practices of chickpea among small and marginal farmers

From the results it was observed that, meagre per cent of the technological gap was observed among the small and marginal farmers of chickpea in the practices like soil type, land preparation, sowing season, varieties, seed rate, spacing and hand weeding. Farmers were well versed with these practices and they did not incur many expenses, these practices are easy to carry out.
By practicing these practices in desired way one could get good yield and economic returns. These might the reasons for above findings.

Huge technological gap was observed in application of FYM (75 and $78.33 \%$ ). This may be due to lack of availability of sufficient quantity of FYM due to medium level of livestock possession. 88.33 and 93.33 per cent of gap was observed among the small and marginal farmers respectively in intercultural operation. This may be due to the fact that, chickpea is a rabi crop, weed intensity is less due to low rain fall during crop period.

More technological gap was observed in use of herbicides, growth regulator and nipping. This may be due to lack of knowledge about these practices and nipping practice is laborious, time consuming and expensive.

Less technological gap was observed in use of chemicals for management pod borer. This may be due to, infestation of pod borer leads severally impact on yield. As a result majority of the farmers adopted the recommended plant protection measures to control the pod borer.

Table.1 Overall technological gap about chickpea improved cultivation practices among small and marginal farmers

$\mathrm{n}=120$

\begin{tabular}{|c|c|c|c|c|c|c|c|}
\hline \multirow[t]{2}{*}{ Sl.No. } & \multirow[t]{2}{*}{ Catagories } & \multicolumn{2}{|c|}{$\begin{array}{l}\text { Small farmers } \\
\qquad\left(n_{1}=60\right)\end{array}$} & \multicolumn{2}{|c|}{$\begin{array}{c}\text { Marginal } \\
\text { farmers } \\
\left(\mathrm{n}_{2}=60\right)\end{array}$} & \multicolumn{2}{|c|}{ Pooled data } \\
\hline & & $\mathbf{F}$ & $\%$ & $\mathbf{F}$ & $\%$ & $\mathbf{F}$ & $\%$ \\
\hline 1 & Low (Mean - 0.425*SD) & 8 & 13.33 & 11 & 18.33 & 19 & 15.83 \\
\hline 2 & Medium (Mean $\pm 0.425 * \mathrm{SD})$ & 50 & 83.33 & 26 & 43.33 & 76 & 63.33 \\
\hline \multirow[t]{5}{*}{3} & High $($ Mean $+0.425 *$ SD $)$ & 2 & 3.33 & 23 & 38.33 & 25 & 20.83 \\
\hline & Mean & \multicolumn{2}{|c|}{32.01} & \multicolumn{2}{|c|}{39.46} & \multicolumn{2}{|c|}{35.71} \\
\hline & SD & \multicolumn{2}{|c|}{5.82} & \multicolumn{2}{|c|}{7.21} & \multicolumn{2}{|c|}{7.52} \\
\hline & Mann Whitney-U test & \multicolumn{6}{|c|}{ SF Vs MF- $.000 * *$} \\
\hline & \multicolumn{7}{|c|}{$* *=$ Significant at $1 \%$ level } \\
\hline
\end{tabular}


Table.2 Technological gap with respect to improved cultivation practices of chickpea among small and marginal farmers

$\mathrm{n}=120$

\begin{tabular}{|c|c|c|c|}
\hline \multirow{2}{*}{$\begin{array}{l}\text { Sl. } \\
\text { No. }\end{array}$} & \multirow{2}{*}{ Practices } & \multicolumn{2}{|c|}{ Technological gap (in \%) } \\
\hline & & $\begin{array}{c}\text { Small farmers } \\
\left(\mathbf{n}_{1}=60\right)\end{array}$ & $\begin{array}{l}\text { Marginal farmers } \\
\qquad\left(\mathbf{n}_{2}=60\right)\end{array}$ \\
\hline 1 & Soil type & 20.00 & 35.00 \\
\hline 2 & Land preparation & 11.67 & 25.00 \\
\hline 3 & FYM application & 75.00 & 78.33 \\
\hline 4 & Sowing season & 18.33 & 28.33 \\
\hline 5 & Varieties & 10.00 & 15.00 \\
\hline 6 & Seed rate & 35.00 & 28.33 \\
\hline 7 & Seed treatment & 85.00 & 93.34 \\
\hline 8 & Seed cum fertilizer drill & 0.00 & 0.00 \\
\hline 9 & Spacing & 8.33 & 16.67 \\
\hline 10 & Intercropping & 100.00 & 100.00 \\
\hline 11 & Thinning & 100.00 & 100.00 \\
\hline 12 & Intercultivation & 88.33 & 93.33 \\
\hline 13 & Spraying of Urea & 100.00 & 100.00 \\
\hline \multirow[t]{3}{*}{14} & \multicolumn{3}{|l|}{ Weed management } \\
\hline & Hand weeding & 25.00 & 45.00 \\
\hline & Herbicides & 85.00 & 88.34 \\
\hline 15 & Nipping & 70.00 & 86.67 \\
\hline 16 & Growth regulator & 90.00 & 91.67 \\
\hline \multirow[t]{3}{*}{17} & \multicolumn{3}{|l|}{ Fertilizer application } \\
\hline & $\mathbf{N}$ & 35.00 & 51.67 \\
\hline & $\mathbf{P}$ & 40.00 & 71.67 \\
\hline \multirow[t]{4}{*}{18} & \multicolumn{3}{|l|}{ Plant Protection measures } \\
\hline & Pod borer & 21.67 & 30.00 \\
\hline & Wilt & 100.00 & 100.00 \\
\hline & Sterility mosaic & 100.00 & 100.00 \\
\hline 19 & Neem seed kernel extract/ Neem oil & 100.00 & 100.00 \\
\hline 20 & Use of chilly and garlic solution & 100.00 & 100.00 \\
\hline 21 & \multicolumn{3}{|l|}{ Integrated Pest Management } \\
\hline $\mathbf{a}$ & Deep summer ploughing & 11.67 & 25.00 \\
\hline b & Chickpea+ 200gm pundi/jawar & 0.00 & 0.00 \\
\hline b & I Spray (20-30 DAS) & 75.00 & 71.67 \\
\hline c & $\begin{array}{l}\text { II Spray-At the stage of 50\% } \\
\text { flowering }\end{array}$ & 25.00 & 33.33 \\
\hline d & When larval population is more & 100.00 & 100.00 \\
\hline
\end{tabular}


Table.3 Correlation coefficient (r) between technological gap of chickpea among small and marginal farmers with their independent variables

\begin{tabular}{|c|c|c|c|}
\hline Sl. No. & Independent variables & $\begin{array}{l}\text { Small farmers } \\
\quad\left(n_{1}=60\right)\end{array}$ & $\begin{array}{l}\text { Marginal farmers } \\
\qquad\left(n_{2}=60\right)\end{array}$ \\
\hline 1 & Age & $0.180^{\mathrm{NS}}$ & $0.090^{\mathrm{NS}}$ \\
\hline 2 & Education & $-0.372^{* *}$ & $-0.303 * *$ \\
\hline 3 & Farming experiences & $-0.213 * *$ & $0.060^{\mathrm{NS}}$ \\
\hline 4 & Land holding & $0.043^{\mathrm{NS}}$ & $-0.097^{\mathrm{NS}}$ \\
\hline 5 & Annual income & $0.101^{\mathrm{NS}}$ & $-0.355^{* *}$ \\
\hline 6 & Cropping intensity & $-0.168 *$ & $-0.187^{*}$ \\
\hline 7 & Household materials & $-0.102^{\mathrm{NS}}$ & $0.050^{\mathrm{NS}}$ \\
\hline 8 & Farm implements & $0.229^{\mathrm{NS}}$ & $0.198^{\mathrm{NS}}$ \\
\hline 9 & Livestock possession & $0.024^{\mathrm{NS}}$ & $0.193^{\mathrm{NS}}$ \\
\hline 10 & Extension participation & $-0.268^{*}$ & $-0.144^{\mathrm{NS}}$ \\
\hline 11 & Extension contact & $0.004^{\mathrm{NS}}$ & $-0.378 * *$ \\
\hline 12 & Mass media participation & $0.042^{\mathrm{NS}}$ & $0.046^{\mathrm{NS}}$ \\
\hline 13 & Social participation & $-0.153 *$ & $-0.034^{\mathrm{NS}}$ \\
\hline 14 & Cosmo politeness & $-0.058^{\mathrm{NS}}$ & $0.012^{\mathrm{NS}}$ \\
\hline 15 & Scientific orientation & $-0.176^{*}$ & 0.048 \\
\hline 16 & Innovativeness & $-0.092^{\mathrm{NS}}$ & $-0.236 *$ \\
\hline 17 & Achievement motivation & $-0.243 * *$ & $-0.031^{\mathrm{NS}}$ \\
\hline 18 & Economic motivation & $0.130^{\mathrm{NS}}$ & $-0.204 * *$ \\
\hline 19 & Risk orientation & $0.214^{\mathrm{NS}}$ & $0.109^{\mathrm{NS}}$ \\
\hline 20 & Management orientation & $0.049^{\mathrm{NS}}$ & $0.093^{\mathrm{NS}}$ \\
\hline
\end{tabular}

$* *=$ Significant at $1 \%$ level $\quad *=$ Significant at $5 \%$ level $\quad$ NS $=$ Non Significant 


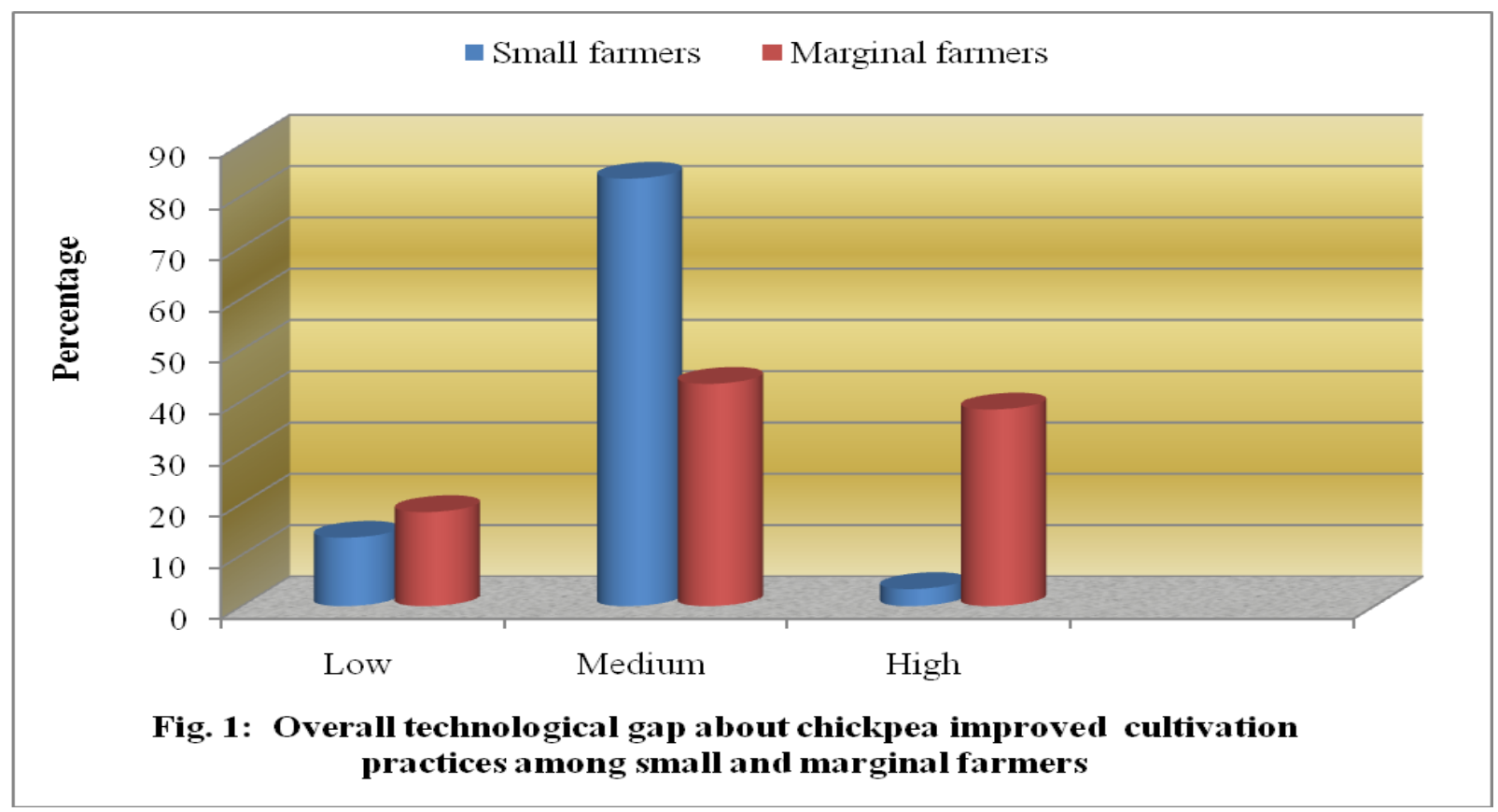

With respect to fertilizer application, thirty five and forty per cent of gap was observed among small farmers in application $\mathrm{N}$ and $\mathrm{P}$ application. Whereas 51.67 and 71.67 per cent of gap existed among marginal farmers. From the above findings it could be concluded that technological gap in more in marginal farmers. This may be due to their less land holding and poor economic conditions, they were unable to apply the recommended quantity of chemical fertilizer.

With regard to integrated pest management, cent per cent of both small and marginal farmers did not follow the practices like mechanical beating of plants, erection of bird perches and pheromone traps. This may be due to lake of knowledge about the above said practices and majority of the farmer belonged to medium cosmopoliteness in nature.

\section{Correlation coefficient (r) between} technological gap of chickpea crop among small and marginal farmers with their independent variables

The data depicted in the Table 3 that, In case of small farmers, education and farming experiences were found negatively significant at 1 per cent level of probability. The other variables found negatively correlated and significant at 5 per cent level of probability were cropping intensity, extension participation, social participation and scientific orientation with technological gap. The table also revealed that, In case of marginal farmers, education, annual income and economic motivation of were found negatively significant at 1 per cent level of probability. Further, the variables which were negatively significant at 5 per cent level of probability are cropping intensity, extension participation and innovativeness.

From the above results the study could be concluded that, majority of the small farmers $(83.33 \%)$ and marginal farmers $(43.33 \%)$ of chickpea crop belonged to medium technological gap category. Whereas, meager per cent of the technological gap was observed among the small and marginal farmers of chickpea in the practices like soil type, land preparation, sowing season, varieties, seed rate, spacing and hand weeding and huge technological gap was observed in application of FYM, intercultivation, use of 
herbicides, growth regulator and nipping. With regard to integrated pest management, cent per cent of both small and marginal farmers did not follow the practices like mechanical beating of plants, erection of bird perches and pheromone traps. Over all technological gap with respect adoption of improved cultivation practices of chickpea were medium has indicated the vast potential for improving the adoption level of improved cultivation practices by chickpea growers. This calls for planning of integrated extension strategies by convergence of Karnataka State Department of Agriculture, State Agricultural Universities, Private extension organizations and NGOs to reduce technological gap.

\section{References}

Gupta, A. K. and Srivastava, J. P., 2002, Technological gap in soybean cultivation. Indian Res. J. Ext. Edu., 13(1/2): 145-146.

Nikhade, D. M., Bhople, R. S. and Kale, N. M., 1997, Technological gap in cultivation of redgram, greengram, and Bengal gram in Gulbarga district of Karnataka. Indian J. Ext. Edu., 33(1-2): $72-75$.

Roy Burman, R., Singh, S. K., Lakhan Singh and Singh, A. K., 2008. Extension Strategies for increasing Pulses Production for Evergreen Revolution. Indian Res. J. Ext. Edu., 8 (1): 5-8

Sanjay Kumar, Ravindra Singh and Akilesh Singh, 2014, Assessment of gaps in pulse production in Hamirpur district of Himachal Pradesh. Indian Res. J. Ext. Edu., 14(2): 20-24

Satyanarayan Soni and Kurmvanshi, S. M., 1999, Technological status (adoption pattern) of soybean cultivation in district Sagar of Madhya Pradesh. Crop. Res., 18(1): 150-154.

Tomar, L. S. and Sharma, P. B., 2002, Yield and technological knowledge gap in soybean cultivation in grid region of Madhya Pradesh. JNKVV., Res. J., 36 (1/2): 115-117.

\section{How to cite this article:}

Krishnamurthy, A. T. and Meti, S. K. 2020. Technological Gap among Small and Marginal Farmers in Adoption of Improved Cultivation Practices of Chickpea Crop. Int.J.Curr.Microbiol.App.Sci. 9(01): 813-819 doi: https://doi.org/10.20546/ijcmas.2020.901.087 